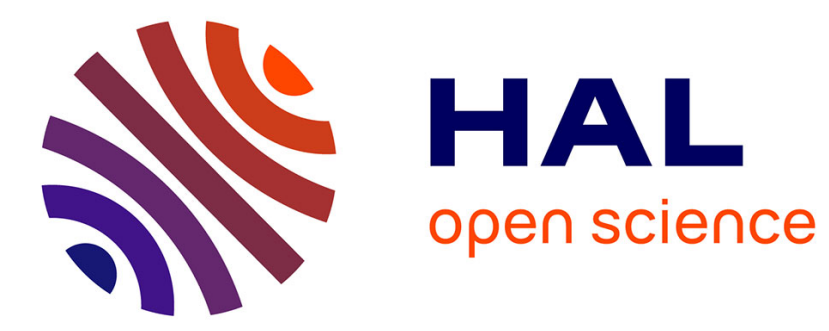

\title{
Effect of Degree of Glycosylation on Charge of Glucose Oxidase and Redox Hydrogel Catalytic Efficiency
}

Olivier Courjean, Victoria Flexer, Antonin Prévoteau, Emmanuel Suratini, Nicolas Mano

\section{- To cite this version:}

Olivier Courjean, Victoria Flexer, Antonin Prévoteau, Emmanuel Suratini, Nicolas Mano. Effect of Degree of Glycosylation on Charge of Glucose Oxidase and Redox Hydrogel Catalytic Efficiency. ChemPhysChem, 2010, 11 (13), pp.2795-2797. 10.1002/cphc.201000178 . hal-00520198

\section{HAL Id: hal-00520198 \\ https://hal.science/hal-00520198}

Submitted on 29 Sep 2017

HAL is a multi-disciplinary open access archive for the deposit and dissemination of scientific research documents, whether they are published or not. The documents may come from teaching and research institutions in France or abroad, or from public or private research centers.
L'archive ouverte pluridisciplinaire HAL, est destinée au dépôt et à la diffusion de documents scientifiques de niveau recherche, publiés ou non, émanant des établissements d'enseignement et de recherche français ou étrangers, des laboratoires publics ou privés. 


\title{
Effect of Degree of Glycosylation on Charge of Glucose Oxidase and Redox Hydrogel Catalytic Efficiency
}

\author{
Olivier Courjean, Victoria Flexer, Antonin Prévoteau, Emmanuel Suraniti, and Nicolas Mano*[a]
}

For most redox enzymes, the reaction center is deeply buried inside the protein structure. ${ }^{[1]}$ The peptide chain of both native enzymes produced in fungi and enzymes overexpressed in eukaryotic cells are surrounded by a sugar shell, increasing both the molecular size and the distance between the active redox center and the outside surface. This latter characteristic is of upmost importance for electron transfer, either via a redox mediator or directly to an electrode surface. This is for instance the case of the $\mathrm{FAD} / \mathrm{FADH}_{2}$ redox centers of glucose oxidase (GOX). ${ }^{[2]}$ We have recently shown that a monolayer of an almost fully deglycosylated GOX from Aspergillus niger is able to directly oxidize glucose starting at a potential close to that of $\mathrm{FAD} / \mathrm{FADH}_{2}{ }^{[3]}$ Later, in an attempt to further increase the rate of electron transfer from the $\mathrm{FADH}_{2}$ centers to the $\mathrm{Os}^{3+}$ mediators in an enzyme/polymer hydrogel matrix, we compared native and deglycosylated GOXs from $A$. niger. ${ }^{[4]}$ Interestingly we found that the latter forms a more efficient redox hydrogel structure that yields up to $38 \%$ improved glucose oxidation, but that the intrinsic electron-transfer rate remains the same as for the native enzyme.

Herein, to further explore and understand the effect of the glycosylation of GOX for electrochemical applications, we chose to study a GOX from Penicillium amagasakiense. To do so, GOX with three degrees of glycosylation were produced in: yeast (yGOXpenag), further deglycosylated (dyGOXpenag) and in bacteria (bGOXpenag). We chose this species because compared to A. niger, this GOX exhibits more advantageous kinetics. Both affinity and catalytic constant for glucose oxidation are higher $\left(K_{\mathrm{M}} \sim 7 \mathrm{mM} ; k_{\mathrm{cat}} \sim 2000 \mathrm{~s}^{-1}\right)$, in oxygen-saturating conditions. ${ }^{[5,6]}$ Ultimately, the anode of a biofuel cell made with GOX from $P$. amagasakiense, rather than with $A$. niger, would be more efficient in physiological media (glucose concentration in blood is $\sim 5-8 \mathrm{~mm}){ }^{[7,8]}$

Glucose oxidase from $P$. amagasakiense was successfully overexpressed and secreted in active form by $P$. pastoris and exhibits biochemical properties very similar to the native enzyme from $P$. amagasakiense. This is a $\sim 146 \mathrm{kDa}$ flavoenzyme, $10 \mathrm{wt} \%$ glycosylated. The deglycosylated enzyme was obtained by incubating for $4 \mathrm{~h}$ the yGOXpenag with endoglycosidase $\mathrm{H}$. The dyGOXpenag exhibits a molecular weight of

[a] Dr. O. Courjean, ${ }^{+}$Dr. V. Flexer, ${ }^{+}$A. Prévoteau, ${ }^{+}$Dr. E. Suraniti, ${ }^{+}$Dr. N. Mano Université de Bordeaux

Centre de Recherche Paul Pascal (CRPP)- UPR 8641

Avenue Albert Schweitzer, 33600 Pessac (France)

Fax: $(+33)$ 5-5684-5600

E-mail:mano@crpp-bordeaux.cnrs.fr

$\left.{ }^{+}\right]$These authors contributed equally to this work.

Supporting information for this article is available on the WWW under http://dx.doi.org/10.1002/cphc.201000178.
$139.5 \mathrm{kDa}$, indicating a large but partial deglycosylation. The bGOXpenag was obtained by a procedure adapted from a protocol by Witt et al. ${ }^{[5]}$ This is a non-glycosylated enzyme with a molecular weight of $132.1 \mathrm{kDa}$, in agreement with the mass calculated from the primary amino acid sequence. The homogeneity and the molecular weight of the three purified enzymes were checked by SDS-PAGE (10\%) followed by Coomassie blue staining and mass spectrometry. To confirm that two FAD were bound per protein, the FAD concentration was calculated from the UV/Vis absorption at $460 \mathrm{~nm} \quad(\varepsilon=$ $\left.12.83 \mathrm{~mm}^{-1} \mathrm{~cm}^{-1}\right)$ and the protein concentration by its absorption at $280 \mathrm{~nm}\left(\varepsilon=263 \mathrm{~mm}^{-1} \mathrm{~cm}^{-1}\right)$. Details about the enzymes production can be found in the Supporting Information. As illustrated in Table 1, there was little difference between the activities of the three enzymes when measured with ABTS or ferrocenium-methanol $\left(\mathrm{FM}_{\mathrm{ox}}\right)$.

Table 1. Comparison of the activities [in $\mathrm{s}^{-1}$ ] of yGOXpenag, dyGOXpenag, bGOXpenag.

\begin{tabular}{|llll|} 
Method $^{[a]}$ & yGOXpenag & dyGOXpenag & bGOXpenag \\
\hline ABTS & $773 \pm 32$ & $771 \pm 27$ & $857 \pm 27$ \\
FM $_{\text {ox }}$ & $859 \pm 94$ & $898 \pm 73$ & $948 \pm 90$ \\
\hline [a] See Supporting Information. & & \\
\hline
\end{tabular}

To compare the apparent surface charge of the three enzymes, we performed fast protein liquid chromatography on an anionic exchange column with a linear gradient of increasing ionic strength. The elution time is directly dependent on the apparent surface charge of the protein and the more negatively charged the enzyme is, the longer it will be bound to the column.

Figure 1 shows the resulting elution profiles obtained for the yGOXpenag (thick line), the dyGOXpenag (thin line) and the bGOXpenag (dashed line). It shows that the non-glycosylated bGOXpenag has an apparent surface charge more negative than the $y G O x p e n a g$ and that deglycosylation of the latter increases its anionic behaviour. Deglycosylation of the yGOXpenag may expose negatively charged residues such as aspartic or glutamic acid. These results prove that the amount of negative surface charges exposed by the protein follows the trend of its deglycosylation.

To study the effect of the glycosylation on the glucose electrooxidation current, each enzyme was immobilized on $5 \mathrm{~mm}$ diameter glassy carbon electrodes with an osmium based redox polymer, PVP-Os(1,1'-dimethyl-2,2'biimidazole $)_{2}-2$ $[6 \text { methylpyrid-2yl]imidazole })^{2+/ 3+}$. Electrostatic interaction be- 


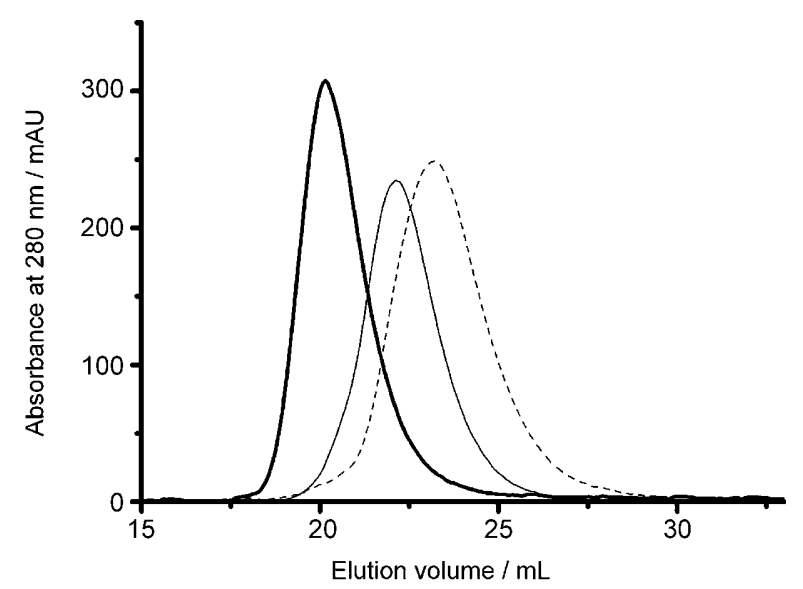

Figure 1. Elution chromatogram at pH 8 of yGOXpenag (thick line), dyGOXpenag (thin line) and bGOXpenag (dashed line) performed on an anionic exchange column.

tween the negatively charged enzyme and the positively charged polymer favours a close distribution of the $\mathrm{Os}^{2+13+}$ around the bioelectrocatalysts. ${ }^{[9]}$ The hydrogel was cross-linked using a constant amount of $20 \mu \mathrm{g} \mathrm{cm}^{-2}$ of polyethylene glycol (400) diglycidyl ether (PEGDGE). To compare the three bioelectrocatalysts, electrodes with the same molar composition of enzyme/polymer and PEGDGE were prepared for 5 different enzyme/polymer ratios as previously described. ${ }^{[4]}$ The total loading of the electrodes varied slightly because of the difference between the molecular weight of the three enzymes and was less than $7 \%$. Figure 2 shows the dependence of the glucose electrooxidation current density at saturation as a function of the enzyme molar amount in the 63.3 to $866 \mathrm{pmol} \mathrm{cm}^{-2}$ range.

A similar trend was observed for the three enzymes. As already shown earlier, the current increases with the enzyme molar amount $\left(\Gamma_{\text {enz }}\right)$ before decreasing due to a lack of redox polymer. ${ }^{[10]}$ The maximum current density was reached for $\Gamma_{\text {enz }} \sim 443 \mathrm{pmolcm}^{-2}\left(1451 \mu \mathrm{Acm}^{-2}\right)$ for bGOXpenag while it

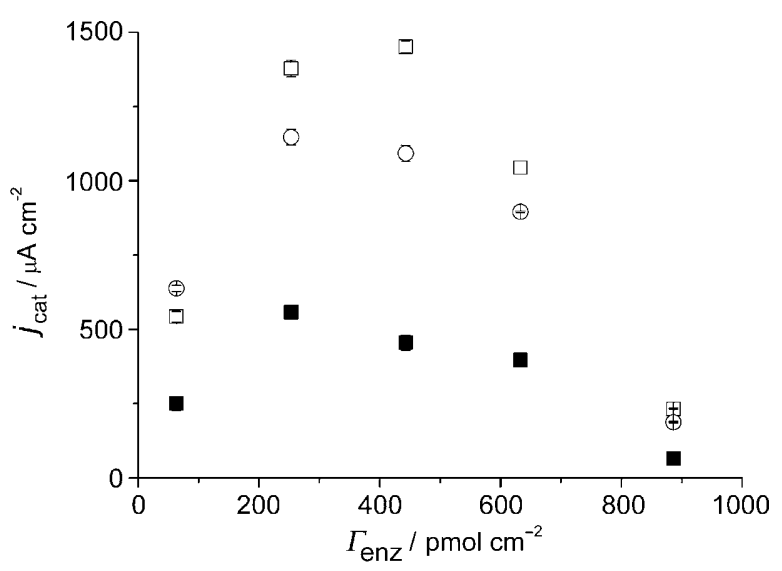

Figure 2. Dependence of the current density on the GOX molar amount measured at $+0.3 \mathrm{~V}$ vs Ag/AgCl. yGOXpenag ( $(\mathbf{)})$, dyGOXpenag $(\circ)$ and bGOXpenag (口). $20 \mathrm{~mm}$ phosphate buffer $\mathrm{pH} 7+0.14 \mathrm{M} \mathrm{NaCl}, 100 \mathrm{~mm}$ glucose, $37^{\circ} \mathrm{C}, 500 \mathrm{rpm}, 5 \mathrm{mV} \mathrm{s}^{-1}$, under Ar. was $\Gamma_{\text {enz }} \sim 253 \mathrm{pmolcm}^{-2}\left(1146 \mu \mathrm{Acm}^{-2}\right)$ for dyGOXpenag and yGOXpenag $\left(557 \mu \mathrm{Acm}^{-2}\right)$. Surprisingly, even though the specific activities of the enzymes are almost identical (Table 1), at $\Gamma_{\text {enz }} \sim 443 \mathrm{pmolcm}^{-2}, J_{\text {cat }}$ is $140 \%$ higher for the dyGOXpenag than it is for the yGOXpenag and $J_{\text {cat }}$ is $220 \%$ higher for the bGOXpenag than it is for yGOXpenag. Interestingly the evolution of $J_{\text {cat }}$ follows the trend of the elution times observed in the anionic exchange column (Figure 1). This points out a probable correlation between the global catalytic efficiency of the hydrogel and the extent of negative charges exposed on the surface of the enzyme (see Supporting Information).

Earlier, we showed that the higher current density obtained by incorporating deglycosylated GOx from $A$. niger into a redox hydrogel was due to a more efficient hydrogel structure rather than a better intrinsic electron transfer. ${ }^{[4]}$ However, this does not seem to be the case in the present system under study. The electrochemical response of the films made of the same molar amount of Os and different enzymes, in the absence of substrate, was similar. The difference $(\sim 15 \%)$ observed in characteristic parameters such as the width of the peak at half height, apparent electron diffusion coefficient and the amount of Os sites effectively connected to the electrode, was not distinguishable from the error bar for each enzyme electrodes (CVs in the absence of substrate are shown in Supporting information). In addition, we showed that the specific activities for the three different enzymes are almost identical (Table 1). Therefore, we hypothesize that a more negatively charged enzyme would favor a better and more efficient electron transfer between the FAD redox center and $\mathrm{Os}^{3+}$. To support this hypothesis, we also performed experiments with a more negatively charged and slightly bigger enzyme, that is, GOx from A. niger. This is a $158 \mathrm{kDa}$ enzyme, $\sim 20 \mathrm{wt} \%$ glycosylated with an activity of $958 \mathrm{~s}^{-1}$ ( $\sim$ bGOXpenag). At $\Gamma \sim$ $443 \mathrm{pmol} \mathrm{cm}^{-2}, J_{\text {cat }}$ is $34 \%$ higher for the native GOX from $A$. niger than it is for bGOxpenag, in good agreement with our hypothesis.

In summary, downsizing the enzyme's dimensions or using truncated enzymes may offer new possibilities to circumvent poor electrical contact between enzymes and electrode surfaces. However, this might not be the optimal strategy for mediated electron transfer of enzymes trapped in redox hydrogels. In this paper, our results seem to indicate that the surface charge of the enzyme rather than its size is the main parameter that governs a good interaction between the polycationic redox polymer and the polyanionic enzyme resulting in higher current densities.

\section{Experimental Section}

The electrochemical experiments were carried out on a potentiostat ( $\mathrm{CH}$ Instruments, model $\mathrm{CHI} 660 \mathrm{C}$, Austin, TX, USA) with a dedicated computer. $5 \mathrm{~mm}$ diameter glassy carbon electrodes (Pine Instrument, Raleigh, NC) were used as working electrodes. A platinum spiral wire was used as counter electrode and all potentials were referred to a $\mathrm{Ag} / \mathrm{AgCl}(3 \mathrm{M} \mathrm{NaCl}$ ) electrode (BAS, West Lafayette, IN). All electrochemical measurements were performed in a water-jacked electrochemical cell with $20 \mathrm{~mm}$ phosphate buffer 
$(\mathrm{pH} 7+0.14 \mathrm{M} \mathrm{NaCl})$ at $37^{\circ} \mathrm{C}$. The temperature was controlled by an isothermal circulator (Jeio Tech, Seoul, Korea). Argon was bubbled for $30 \mathrm{~min}$ before all experiments and $\mathrm{Ar}$ atmosphere was maintained during measurements. Chemicals, materials and electrode preparation were previously described. ${ }^{[11]}$ The Os polymer was a generous gift from Abbott Diabetes Care ${ }^{\circledR}$.

Comparison of apparent surface charge of different GOXs by FPLC. The same amounts $(0.5 \mathrm{mg})$ of yGOXpenag, dyGOXpenag or bGOXpenag were dialyzed in $20 \mathrm{~mm}$ phosphate buffer ( $\mathrm{pH}$ 8.0), which was used as binding buffer. After injection on the HiTrap Q FF anionic exchange column $(1 \mathrm{~mL})$, elution at $1 \mathrm{~mL} \mathrm{~min}{ }^{-1}$ was performed by a linear gradient of 0 to $1 \mathrm{M} \mathrm{NaCl}$. Elution was continuously monitored at $280 \mathrm{~nm}$ and $460 \mathrm{~nm}$ to discriminate between protein and FAD, respectively.

\section{Acknowledgements}

This research was financed by a European Young Investigator Award (EURYI) and la Région Aquitaine. We thank Karen Bertaux for her help with the molecular biology experiments.
Keywords: biofuel cells • biosensors - enzyme engineering enzyme surface charge $\cdot$ glucose oxidase

[1] B. Willner, E. Katz, I. Willner, Curr Opin Biotechnol. 2006, 17, 589-596.

[2] G. Wohlfahrt, S. Witt, J. Hendle, D. Schomburg, H. M. Kalisz, H.-J. Hecht, Acta Crystallographica Section D. 1999, D55, 969-977.

[3] O. Courjean, F. Gao, N. Mano, Angew. Chem. 2009, 121, 6011-6013; Angew. Chem. Int. Ed. 2009, 48, 5897-5899.

[4] A. Prévoteau, O. Courjean, N. Mano, Electrochem. Commun. 2010, 12, $213-215$.

[5] S. Witt, M. Singh, H. M. Kalisz, Appl. Environ. Microbiol. 1998, 64, $1405-$ 1411.

[6] S. Nakamura, S. Fujiki, J. Biochem. 1968, 63, $51-58$.

[7] S. C. Barton, J. Gallaway, P. Atanassov, Chem. Rev. 2004, 104, 4867-4886.

[8] I. Willner, Y. Yan, B. Willner, R. Tel-Vered, Fuel Cells 2009, 9, 7-24.

[9] A. Heller, Acc. Chem. Res. 1990, 23, 128-134.

[10] N. Mano, Chem. Commun (Camb). 2008, 2221-2223.

[11] F. Gao, O. Courjean, N. Mano, Biosens. Bioelectron. 2009, 25, 356-361. 